\title{
Process capability improvement through DMAIC for aluminum alloy wheel machining
}

\author{
G. V. S. S. Sharma ${ }^{1}$ (1) P. Srinivasa $\operatorname{Rao}^{2} \cdot$ B. Surendra Babu ${ }^{3}$
}

Received: 13 December 2016/Accepted: 7 July 2017/Published online: 24 July 2017

(C) The Author(s) 2017. This article is an open access publication

\begin{abstract}
This paper first enlists the generic problems of alloy wheel machining and subsequently details on the process improvement of the identified critical-to-quality machining characteristic of A356 aluminum alloy wheel machining process. The causal factors are traced using the Ishikawa diagram and prioritization of corrective actions is done through process failure modes and effects analysis. Process monitoring charts are employed for improving the process capability index of the process, at the industrial benchmark of four sigma level, which is equal to the value of 1.33. The procedure adopted for improving the process capability levels is the define-measure-analyze-improvecontrol (DMAIC) approach. By following the DMAIC approach, the $C_{\mathrm{p}}, C_{\mathrm{pk}}$ and $C_{\mathrm{pm}}$ showed signs of improvement from an initial value of $0.66,-0.24$ and 0.27 , to a final value of $4.19,3.24$ and 1.41 , respectively.
\end{abstract}

Keywords Alloy wheel · CTQ (critical-to-quality) characteristic · DMAIC (define-measure-analyze-improvecontrol) - Ishikawa diagram - PFMEA (process failure modes and effects analysis) $\cdot$ Control charts

G. V. S. S. Sharma

sarma.gvss@gmail.com

1 Department of Mechanical Engineering, GMR Institute of Technology, Rajam, A.P. 532127, India

2 Department of Mechanical Engineering, Centurion University, Parlakhemundi, Odisha 761211, India

3 Department of Industrial Engineering, GITAM University, Visakhapatnam, A.P. 530045, India

\section{Introduction}

The past two decades have seen the realization of the manufacturing firms towards quality consciousness. In pursuit of quality, the main concerns for alloy wheel machining process areas follows: alloy wheel unclean, surface finish deterioration, non-conformance to geometric and dimensional specification, over hump diameter over size or undersize. The spoke profile and rim profile not as per the requirement lead to non-optimal weight and premature wheel failure in the radial fatigue test. Over used machining inserts result in surface finish deterioration and a patchy surface in the paint line. The prime concern in machining is the problem of unclean leading to rework. Hence, aluminum alloy wheel machining constitutes an important area of study for improvement of process capability. In this process more prominence is laid on prevention of defects rather than simply detecting and rejecting the defect in the usual traditional end inspection quality check.

In order to obtain an improved end product quality, process control plays an important role instead of end quality inspection. The modern work on process control was pioneered by Schilling (1994) and was succeeded by employing process control charts by John (1994). Process capability indices, process failure modes and effects analysis (PFMEA), Taguchi's orthogonal array, control charts and process capability monitoring figure comprise the various tools for achieving the sustained process improvements (Lin 2004; Rupinder Singh 2011; Lin et al. 2013; Kumaravadivel and Natarajan 2013; Mariajayaprakash et al. 2013; Chen et al. 2013; Lal et al. 2013; Burlikowska 2005; Yu et al. 2007).

The define-measure-analyze-improve-control (DMAIC) constitutes a systematic procedure for achieving sustained 
Table 1 Project Charter of the DMAIC project pertaining to the machining of alloy wheel manufacturing

\begin{abstract}
Objectives
To recognize alloy wheel center hole boring operation as a process capable operation

To relieve the centre hole boring operation from being as a bottle-neck and with a smooth work-in-flow without any staggered inventory
\end{abstract}

Deliverables and success metrics

To achieve the process potential capability index and process performance capability index i.e., $C_{\mathrm{p}}$ and $C_{\mathrm{pk}}$ values for the centre hole boring operation of the alloy wheel, to be greater than 1.33, i.e., more than 4 sigma levels

The $C_{\mathrm{p}}$ and $C_{\mathrm{pk}}$ values to be achieved consistently greater than 1.33 for over a persistent period of three months

Team

Team members scope: plant leader, module leader, cell leader, supervisors and operators involved in machining of alloy wheel

\begin{tabular}{|c|c|c|c|c|c|c|c|c|c|c|c|c|}
\hline Time-line in months & 1 & 2 & 3 & 4 & 5 & 6 & 7 & 8 & 9 & 10 & 11 & 12 \\
\hline $\mid$ & & & & & & & & & & & & \\
\hline $\begin{array}{l}\text { Defining the scope of the project, formulating } \\
\text { project charter, identifying CTQ characteristic }\end{array}$ & & & & & & & & & & & & \\
\hline $\begin{array}{l}\text { Taking measurements of the CTQ characteristic } \\
\text { under consideration }\end{array}$ & & & & & & & & & & & & \\
\hline $\begin{array}{l}\text { Perform Analysis of the measurements utilizing } \\
\text { different quality tools like cause-and-effect } \\
\text { diagram, FMEA, PM analysis, and ANOVA }\end{array}$ & & & & & & & & & & & & \\
\hline $\begin{array}{l}\text { Improve, control and sustain the improvements } \\
\text { achieved over a continuous period of six months } \\
\text { by implementing the process monitoring charts and } \\
\text { control charts }\end{array}$ & & & & & & & & & & & & \\
\hline
\end{tabular}

Business impact

Raise the process capability levels and awareness of the importance of process monitoring charts in daily production. Reduce the component rejection and rework by $99 \%$ in the first six months after sustenance

\begin{tabular}{|l|l|l|}
\hline S. No. & Components of the project area & Value \\
\hline 1 & Plant turnover of alloy wheels per month & $=8000$ \\
\hline 2 & Total no. of rejects and reworks per production shifts of $8 \mathrm{~h}$ each & $=10$ wheels \\
\hline 3 & Time taken for segregation and rework of components & $=2 \mathrm{~h}$ per day \\
\hline 4 & Production loss due to rejection and rework per month & $=30 \times 2=60 \mathrm{~h}$ \\
\hline 5 & Monetary loss of 2 h delay in the CNC machining cell & $=\$ 5000$ \\
\hline 6 & Total monetary loss per month with 25 working days per month & $=25 \times \$ 5000=\$ 125000$ \\
\hline 7 & By avoiding 99\% of rejections \& rework, the economical savings per month is & $=0.99 \times \$ 125000=\$ 123750$ \\
\hline The values projected above are on the basis for target turnover of about 8000 components per month
\end{tabular}




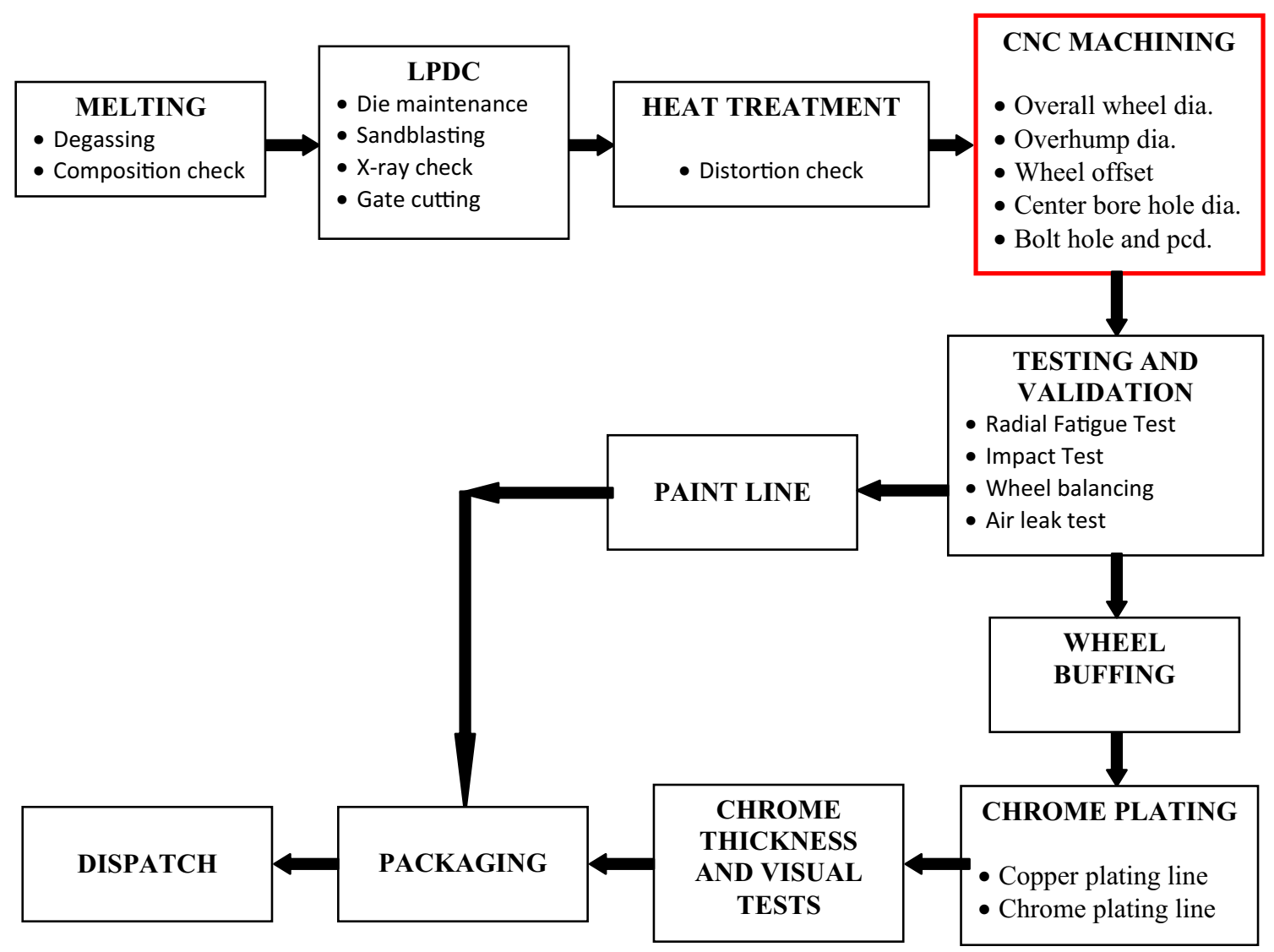

Fig. 1 Process flow chart of A356 aluminum alloy wheel manufacturing process

improvements in the manufacturing process and ultimately in the end product. The DMAIC approach was employed for the quality improvement of the printed circuit boards, integrated circuit (IC) delamination, manufacturing and mechanical execution systems (Tong et al. 2004; Su et al. 2005; Hwang 2006; Gentili et al. 2006). The DMAIC approach was used for standardizing the process parameters involved in the manufacture of optical lens with good surface contour precision in the injection-molding process by Lo et al. (2009). DMAIC approach is followed in varied platforms such as for improving the process parameters and capability of solder printing process, to analyze the manufacturing lines of a brake lever at an automotive components manufacturing company, to improve the fracture resistance of TFT-LCDs and improve the process capability levels of connecting rod and crankshaft manufacturing cells and minimizing variations in food processing industry (Li et al. 2008; Chen et al. 2009; Sahay et al. 2011; Su et al. 2012; Sharma and Rao 2013, 2014; Desai et al. 2015).

Thus, the literature survey indicates that the firms worldwide are adopting the DMAIC procedure for improving the manufacturing process and curtailing down the process rejections. The various firms worldwide are employing the quality control tools for minimizing the deviations and subsequently the number of rejects of the manufactured parts. The present work exemplifies the improvement of machining process capability levels of A356 aluminum alloy wheel.

The structure of the paper is elaborated as follows. This paper starts with introduction and literature survey on DMAIC procedure in "Introduction" section and followed by mapping of manufacturing process flow of alloy wheels in "Alloy wheel manufacturing process flow study" section. Then, the critical-to-quality (CTQ) characteristic of prime importance is identified and the project charter is charted in the Define phase in "Definition phase" section. This is followed by the measurement phase where the dimensional values of the CTQ characteristic are measured and plotted on the process monitoring charts in four successive iterations in "Measurement phase" section. The analysis phase comprises tracing out the causes and prioritizing the corrective actions through the ishikawa diagram and PFMEA in "Analysis phase" section. "Improvement phase" and "Control phase" sections comprise improvement and control phases, respectively, where the process improvement is witnessed in the process monitoring charts. Comparison of the capability 


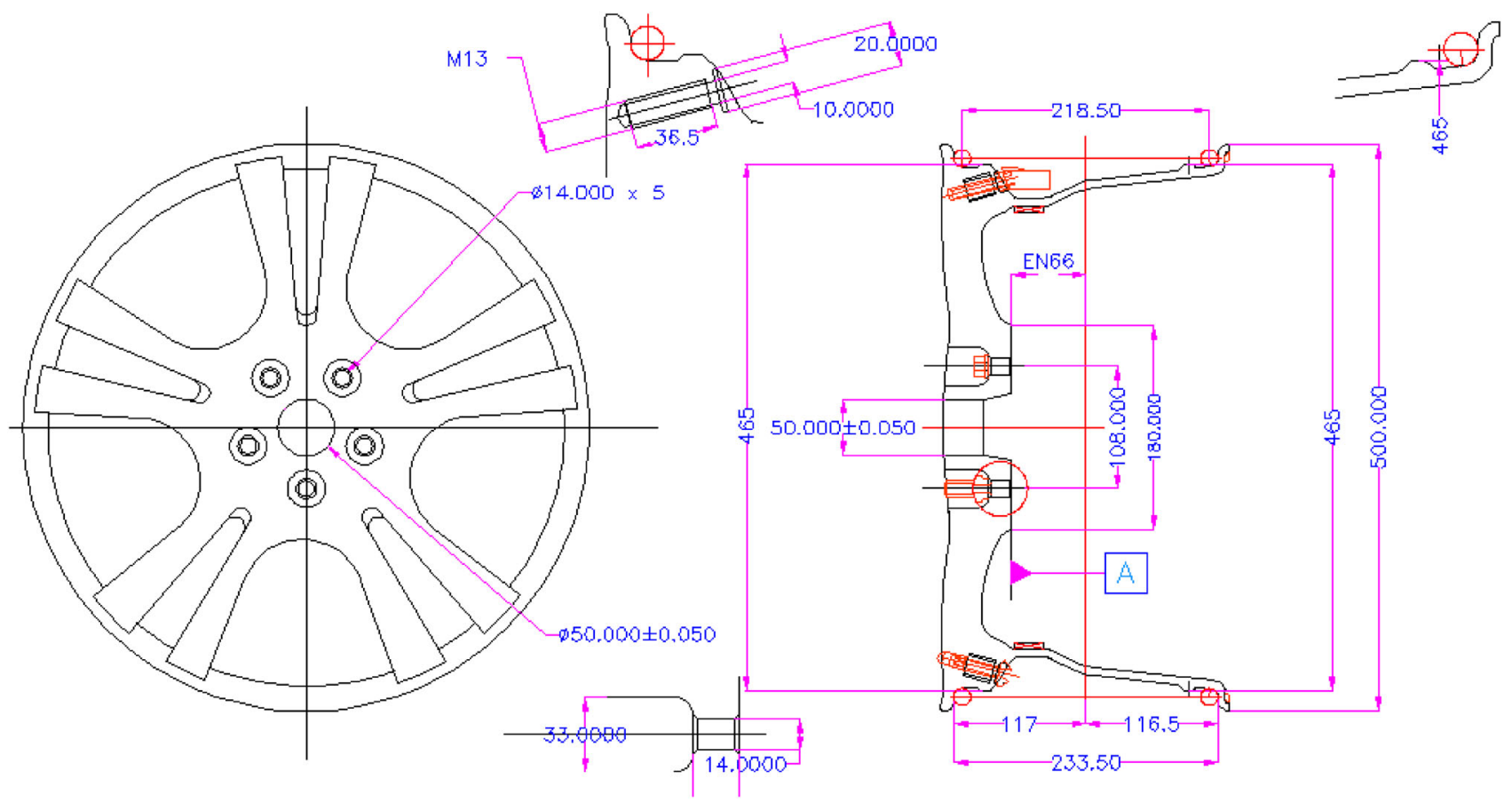

Fig. 2 Alloy wheel machining drawing with center hole diameter of $\varnothing 50.000^{( \pm 0.050)}$

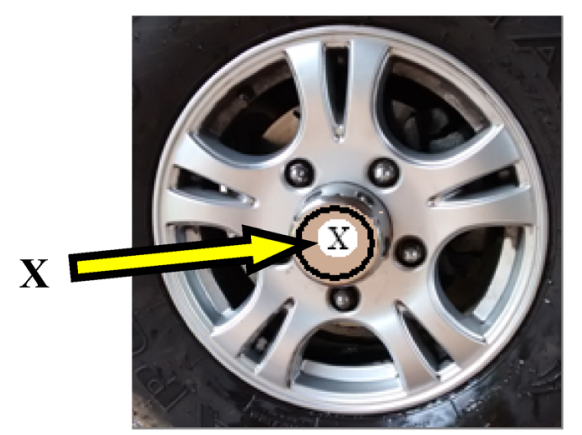

Fig. 3 Alloy wheel in assembly, $X=$ center hole diameter of $\emptyset 50.000^{( \pm 0.050)}$

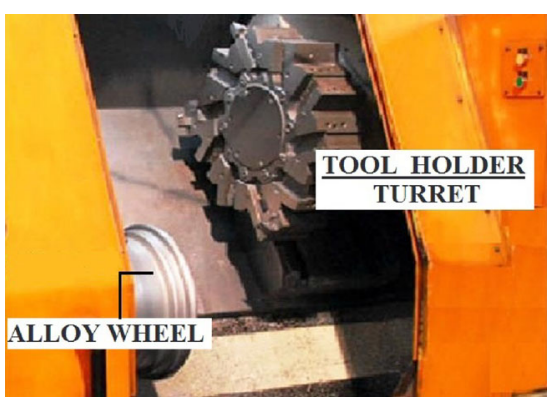

Fig. 4 Set up for center bore diameter machining operation

indices and tolerance zones, using a tolerance capability expert software, is done in "Comparison with a tolerance capability expert software" section. The paper is concluded in "Conclusion" section and followed by references and appendices.

\section{Alloy wheel manufacturing process flow study}

Alloy wheels constitute a very prominent aspect of an automobile. This is because it forms an integral part of overall visual esthetic appeal of the automobile. The A356 aluminum alloy with $7 \%$ silicon as its prime alloying element forms the popular material for the manufacture of automotive alloy wheel castings. The alloy wheel manufacturing process starts with ingots which form the input into the furnace of the melting section. After ladle preheating, the liquid metal treatment (degassing) is performed in the melting section. The die in the die maintenance area is preheated and sandblasted in order to clean the die surface, increase the surface finish and relieve the external surface stresses. Then, the prepared die is preserved in the Die preservation yard. As per the production schedule the required die is retrieved from the die preservation yard and then fitted onto the low-pressure die cast (LPDC) machine unit.

The LPDC machine unit employed here is a vertical cold chamber die casting unit. The wheel casting coming out of the LPDC unit is quenched in water and is sent for checking internal casting defects in the non-destructive $\mathrm{x}$-ray checking machine. After non-destructive $\mathrm{x}$-ray 
Table 2 List of machining operations and corresponding CTQ characteristics

\begin{tabular}{lll}
\hline Machining operation No. & Machining operation & CTQ characteristic confirming to the machining operation \\
\hline 10 & Back face profile machining & Spoke profile \\
20 & Rim machining & Overall wheel dia-back face \\
& & Overall wheel dia-street face \\
& & Over hump dia-street face \\
& Wheel center hub machining & Over hump dia- back face \\
30 & & ET-wheel offset \\
& & Center bore hole dia \\
& & Bolt hole dia \\
40 & Function hole drilling & Bolt hole pitch circle dia (pcd) \\
50 & Wheel deburring & Tire Pressure sensor bore hole dia drilling \\
& Final inspection of CNC machining quality check & Air chuck gage hole dia \\
\hline
\end{tabular}

Table 3 Dimensional measurement readings of CTQ characteristic pertaining to the intial Iteration 1

\begin{tabular}{llllllllllllllll}
\hline S. No & 1 & 2 & 3 & 4 & 5 & 6 & 7 & 8 & 9 & 10 & 11 & 12 & 13 & 14 & 15 \\
\hline I1 & 50.09 & 50.04 & 50.08 & 50.09 & 50.04 & 50.08 & 50.06 & 50.03 & 50.06 & 50.07 & 50.06 & 50.07 & 50.05 & 50.08 & 50.03 \\
\hline S. No & 16 & 17 & 18 & 19 & 20 & 21 & 22 & 23 & 24 & 25 & 26 & 27 & 28 & 29 & 30 \\
\hline I1 & 50.09 & 50.02 & 50.02 & 50.00 & 50.08 & 50.05 & 50.04 & 50.05 & 50.03 & 50.08 & 50.05 & 50.03 & 50.05 & 50.04 & 50.04 \\
\hline
\end{tabular}

check, the alloy wheel casting then follows the gate-cutting process, heat treatment, shot-blasting, CNC machining and air-leak testing. After air-leak test depending on the product requirement the alloy wheel is either sent to the paint line or sent to the Chrome Plating Plant. The paint line mainly consists of degreasing the machined alloy wheel, deoxidizing, conversion coating, pre-heating in dry-off oven, color coating and packing and dispatch. On the other hand, the machined wheels entering the Chrome Plating Plant are subjected to rigorous surface finish improvement by buffing operation. After this it enters the chrome plating process which consists of the copper plating line followed by chrome plating line.

Thus, the manufacturing process of alloy wheel is a complete wholesome process encompassing all the fields of manufacturing ranging from melting in furnace, postmelting treatment, die preparation, sand blasting of die, casting, $\mathrm{x}$-ray inspection of wheel castings, heat treatment, CNC machining, deburring, wheel shot blasting, paint-line process, chrome plating, fatigue test, impact test, CASS (cupric acid salt spray test) and chrome thickness test. The complete manufacturing process of the alloy wheel is charted in Fig. 1.

\section{Definition phase}

The present study focuses on the process improvement of CNC machining where the cast wheels are machined to accurate dimensions and tolerances as per the machining drawing specifications. CNC machining is of prime importance in the process of alloy wheel manufacturing, because it is at this place where the shaping of critical dimensions takes place. From functional view point, the wheel gets ready here, for further functional tests. The machining drawing of the alloy wheel is shown in Fig. 2. The photograph of the alloy wheel in assembly is shown in Fig. 3. Figure 4 depicts the machine set-up where the center bore hole boring operation is performed. Also in this "Define Phase" the Project Charter of the DMAIC project pertaining to the machining of Alloy Wheel is defined and is shown in Table 1. The machining operations of the alloy wheel machining and the corresponding CTQ characteristic pertaining to the machining operation are shown in Table 2. After identifying the multiple CTQ characteristics of machining process it is deduced that the CTQ characteristic of prime importance is the Center Bore hole diameter of $\varnothing \mathbf{5 0 . 0 0 0}{ }^{( \pm \mathbf{0 . 0 5 0})}$, as this CTQ dimension forms 


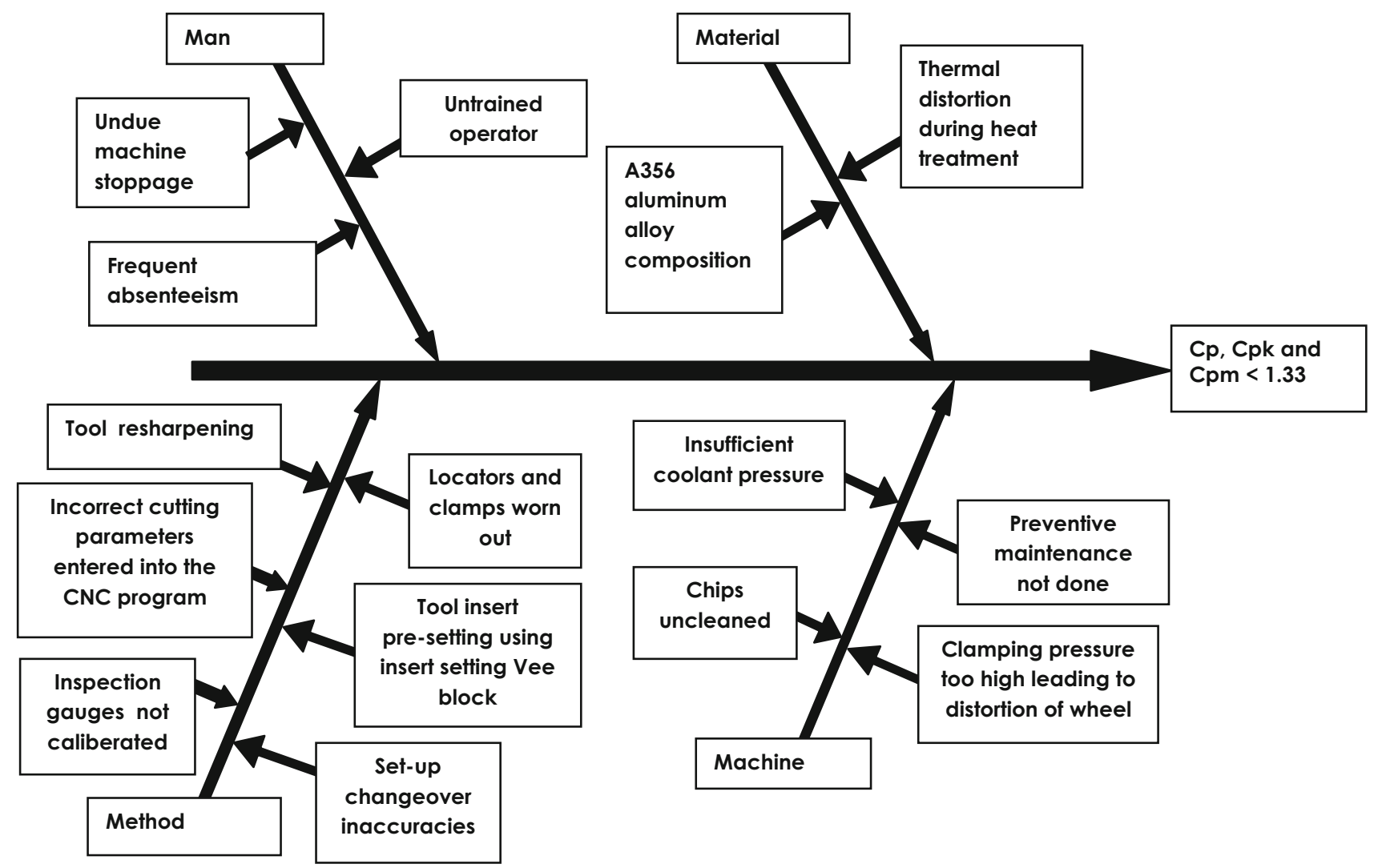

Fig. 5 Cause and Effect Ishikawa diagram

the basic locating dimension for further machining operations, mainly the drilling of pitch circle diameter holes and any deviations of it leads to bottleneck.

\section{Measurement phase}

In measurement phase, first the initial data about the CTQ characteristic is collected. This machining data reflect the initial uncorrected state of the process for which the analysis needs to be carried out for obtaining sustained improvements. Based on the six sigma sample size formula the samples are collected:

$n=\left(\frac{1.96}{\Delta}\right)^{2} P(1-P)$,

where $P$ is the proportion defective that we are estimating (expressed in $\%$ ) and $\Delta$ is the precision or the level of uncertainty in the estimate that we are willing to accept (expressed in \%).

With an estimated proportion defective of $10 \%$ (i.e., $P=0.1)$ and target $\Delta$ of $2.5 \%(\Delta=0.025)$ we estimate the sample size of $n=553$.
Samples of about 800 components are collected. The best fit of 30 consecutive components out of the 800 measured values in each iteration is projected while carrying out the Statistical Process Control during this DMAIC project. This initial data set is termed as Iteration 1 (I1) which is depicted in Table 3. An iteration means a stage depicting the state-of-affairs which reflects the existing condition of the machining process in context of the CTQ characteristic.

The process capability indices $C_{\mathrm{p}}, C_{\mathrm{pk}}$ and $C_{\mathrm{pm}}$ for a target value of $50.010 \mathrm{~mm}$ are obtained as $0.66,-0.04$ and 0.27 , which reflects a large scope of improvement in the process in context of the selected CTQ characteristic.

\section{Analysis phase}

After Measurement Phase the analysis phase succeeds, comprising tracing out the causes for poor process performance through the Ishikawa diagram shown in Fig. 5. The potential failure modes of the boring process are estimated through process failure modes and effects analysis (PFMEA) depicted in Table 4. The PFMEA is 
Table 4 PFMEA sheet

\begin{tabular}{|c|c|c|c|c|c|c|c|c|}
\hline Process name & $\begin{array}{l}\text { Potential } \\
\text { failure }\end{array}$ & $\begin{array}{l}\text { Potential } \\
\text { effect }\end{array}$ & Severity & Potential cause & Occurrence & Current controls & Detection & RPN \\
\hline \multirow[t]{9}{*}{$\begin{array}{l}\text { Center hole diameter } \\
\text { boring operation } \\
\varnothing 50.000(+0.050 /-0.050)\end{array}$} & \multirow[t]{4}{*}{$\begin{array}{c}\text { Bore hole } \\
\text { diameter } \\
\text { oversize }\end{array}$} & $\begin{array}{l}\text { Wheel } \\
\text { wobbling in } \\
\text { assembly }\end{array}$ & 9 & $\begin{array}{l}\text { Incorrect } \\
\text { TOOL insert } \\
\text { pre-setting } \\
\text { using insert } \\
\text { setting Vee } \\
\text { block }\end{array}$ & 9 & $\begin{array}{l}\text { Tool insert setting } \\
\text { mandrel } \\
\text { calibration }\end{array}$ & 8 & 648 \\
\hline & & \multirow[t]{3}{*}{$\begin{array}{l}\text { Loose fitment } \\
\text { of wheel in } \\
\text { assembly }\end{array}$} & \multirow[t]{3}{*}{9} & $\begin{array}{l}\text { Tool } \\
\text { resharpening } \\
\text { not proper }\end{array}$ & 8 & $\begin{array}{l}\text { Tool resharpening } \\
\text { control chart }\end{array}$ & 7 & 504 \\
\hline & & & & $\begin{array}{l}\text { Unclean chips } \\
\text { obstruction }\end{array}$ & 3 & $\begin{array}{l}\text { Chip cleaning made } \\
\text { compulsory in the } \\
\text { operator } \\
\text { instruction sheet }\end{array}$ & 7 & 189 \\
\hline & & & & $\begin{array}{l}\text { Incorrect } \\
\text { cutting } \\
\text { parameters } \\
\text { entered into } \\
\text { the CNC } \\
\text { program }\end{array}$ & 7 & $\begin{array}{l}\text { CNC program lock } \\
\text { with password } \\
\text { protect }\end{array}$ & 8 & 504 \\
\hline & \multirow[t]{3}{*}{$\begin{array}{l}\text { Bore hole } \\
\text { diameter } \\
\text { undersize }\end{array}$} & $\begin{array}{l}\text { Incorrect } \\
\text { wheel } \\
\text { fitment in } \\
\text { assembly }\end{array}$ & 5 & $\begin{array}{l}\text { Incorrect Tool } \\
\text { insert pre- } \\
\text { setting using } \\
\text { insert setting } \\
\text { Vee block }\end{array}$ & 9 & $\begin{array}{l}\text { Tool insert setting } \\
\text { mandrel } \\
\text { calibration }\end{array}$ & 2 & 90 \\
\hline & & \multirow[t]{2}{*}{$\begin{array}{l}\text { Incorrect } \\
\text { location for } \\
\text { bolt hole } \\
\text { drilling }\end{array}$} & 7 & $\begin{array}{l}\text { Tool insert not } \\
\text { indexed }\end{array}$ & 7 & $\begin{array}{l}\text { Tool insert to be } \\
\text { indexed as per the } \\
\text { instructions in } \\
\text { process sheet }\end{array}$ & 3 & 147 \\
\hline & & & & $\begin{array}{l}\text { Set-up } \\
\text { changeover } \\
\text { inaccuracies }\end{array}$ & 5 & $\begin{array}{l}\text { Set-up changeover } \\
\text { instruction to be } \\
\text { followed in } \\
\text { process sheet }\end{array}$ & 2 & 70 \\
\hline & \multirow[t]{2}{*}{$\begin{array}{l}\text { Incorrect } \\
\text { geometrical } \\
\text { tolerance }\end{array}$} & \multirow{2}{*}{$\begin{array}{l}\text { Eccentricity } \\
\text { of PCD } \\
\text { leading to } \\
\text { incorrect } \\
\text { wheel } \\
\text { fitment in } \\
\text { assembly }\end{array}$} & \multirow[t]{2}{*}{7} & $\begin{array}{l}\text { Unclean chips } \\
\text { obstruction } \\
\text { in wheel } \\
\text { location }\end{array}$ & 5 & $\begin{array}{l}\text { Chip cleaning made } \\
\text { compulsory in the } \\
\text { operator } \\
\text { instruction sheet }\end{array}$ & 2 & 70 \\
\hline & & & & $\begin{array}{l}\text { High clamping } \\
\text { pressure } \\
\text { leading to } \\
\text { wheel } \\
\text { distortion }\end{array}$ & 4 & $\begin{array}{l}\text { Clamping pressure } \\
\text { specified in } \\
\text { process sheet }\end{array}$ & 2 & 56 \\
\hline
\end{tabular}

an analysis tool for identifying the effects of the failure modes, causal factors for the process deviations. PFMEA helps the process personnel to prioritize the corrective actions and confirms which causal factor needs to be addressed first. Rankings for Severity of the effects, causal occurrence frequency and detection control ability are allotted from 1 to 10 point scale (Lange et al. 2001). The product of severity, occurrence and detection rankings is the risk priority number (RPN). Suitable corrective actions for the corresponding failure modes are suggested based on the RPN. The RPNs greater than 100 are given top priority.

\section{Improvement phase}

In the Improvement Phase, the causal matrix is formulated for detailing down the causes responsible for the poor performance among the Iterations. This causal matrix is charted in Table 5. From the ANOVA technique (discussed in detail in the Appendix 2) it is deduced that $73 \%$ of variability is due to the improper tool insert setting v-block, inaccuracies in setup changeover and undue machine stoppage. After taking the corrective actions in the successive iterations (dimensional measurements of the CTQ characteristic in the 2nd, 3rd and 4th iterations are 
Table 5 The causal matrix

\begin{tabular}{|c|c|c|c|c|c|c|c|}
\hline $\begin{array}{l}\text { Cause. } \\
\text { No. }\end{array}$ & Category & $\begin{array}{l}\text { Colour } \\
\text { code }\end{array}$ & Cause & $\begin{array}{c}\text { Iteration } \\
1\end{array}$ & $\begin{array}{l}\text { Iteration } \\
\quad 2\end{array}$ & $\begin{array}{c}\text { Iteration } \\
3\end{array}$ & $\begin{array}{l}\text { Iteration } \\
\quad 4\end{array}$ \\
\hline 01 & \multirow{2}{*}{ Material } & & Thermal distortion & $\checkmark$ & & & \\
\hline 02 & & & Alloy composition & $\checkmark$ & & & \\
\hline 03 & \multirow{3}{*}{ Man } & & Untrained operator & $\checkmark$ & & & \\
\hline 04 & & & Undue machine stoppage & & & $\checkmark$ & \\
\hline 05 & & & Frequent absenteeism & & $\checkmark$ & & \\
\hline 06 & \multirow{7}{*}{ Method } & & Tool resharpening & & $\checkmark$ & & \\
\hline 07 & & & $\begin{array}{l}\text { Incorrect cutting parameters entered } \\
\text { into the } \mathrm{CNC} \text { program }\end{array}$ & $\checkmark$ & & & \\
\hline 08 & & & Inspection gauges not calibrated & $\checkmark$ & & & \\
\hline 09 & & & Set-up changeover inaccuracies & & $\checkmark$ & $\checkmark$ & \\
\hline 10 & & & $\begin{array}{l}\text { Tool insert pre-setting using insert } \\
\text { setting Vee block }\end{array}$ & & & $\checkmark$ & \\
\hline 11 & & & Locators and clamps worn out & $\checkmark$ & & & \\
\hline 12 & & & Chips uncleaned & & $\checkmark$ & & \\
\hline 13 & \multirow{4}{*}{ Machine } & & Insufficient coolant pressure & & & & \\
\hline 14 & & & Machine Preventive maintenance & $\checkmark$ & & & \\
\hline 15 & & & $\begin{array}{l}\text { Clamping pressure too high leading } \\
\text { to distortion of wheel }\end{array}$ & $\checkmark$ & & & \\
\hline 16 & & & Frequent changes in ECN & & & & $\checkmark$ \\
\hline
\end{tabular}

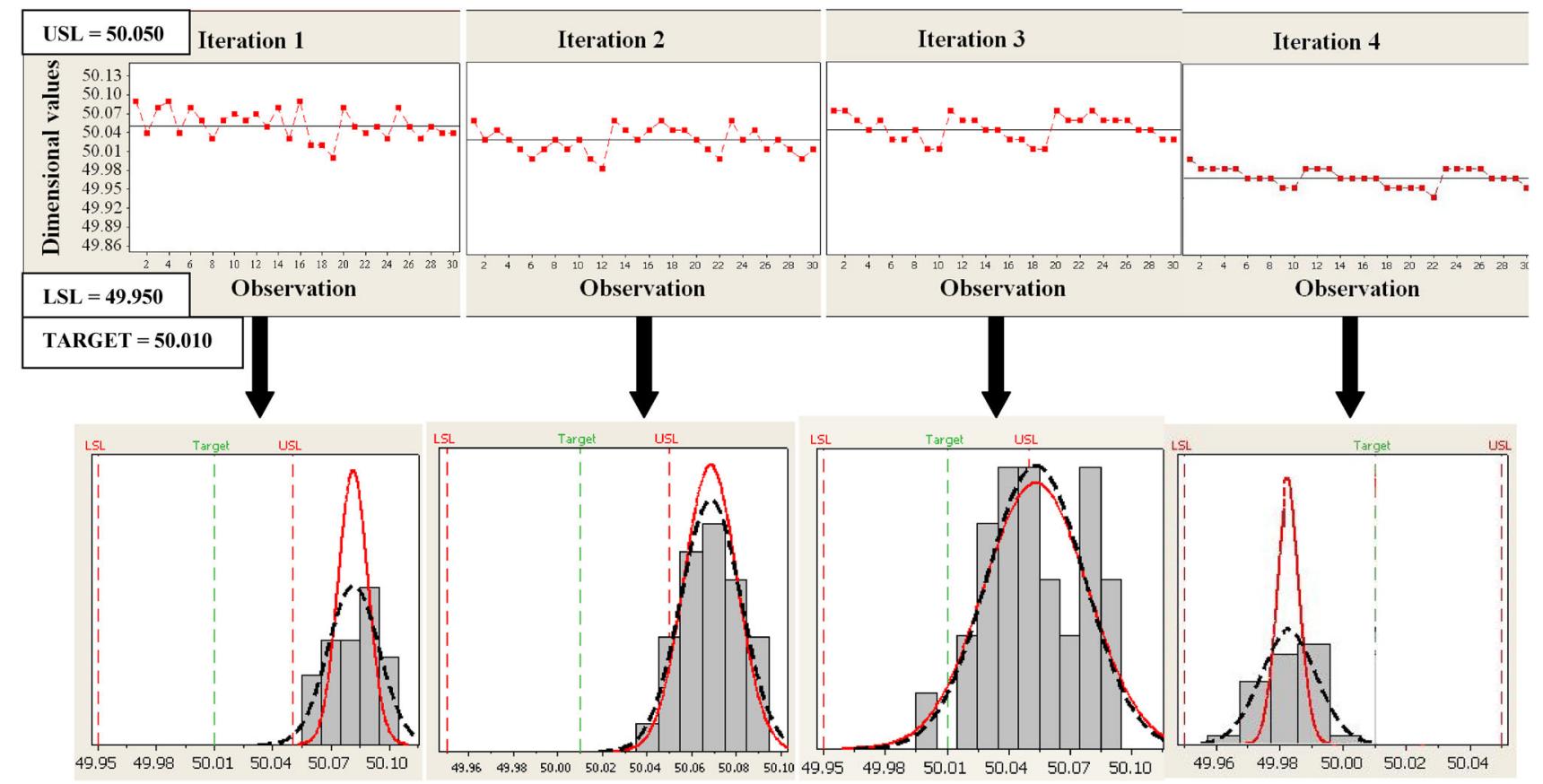

Fig. 6 Process capability analysis depicting run charts and histograms of Iterations 1, 2, 3 and 4

projected in a tabular form in the Appendix 2) and corresponding process capability indices are computed. This datum pertaining to the CTQ characteristic is plotted on the process monitoring charts for performing the process capability analysis and this is shown in Fig. 6.

On analyzing the process monitoring charts it can be deduced that Iteration 1 does not show any significant pattern but in Iteration 2 indicates a cyclic pattern (Du et al. 2013). Upon testing for the causal factors, this cyclic pattern in the observations emerges strongly in Iterations 3 and 4. The reason for this cyclic pattern is elaborated as follows: In order to eliminate the inaccuracies in the boring bar insert setting, after every ten components being machined, the boring bar insert is raised to compensate for constant progressive wear-out of the boring bar insert on continued boring operation. The insert is elevated by about $0.060 \mathrm{~mm}$, over the diametric dimension. This exercise is performed with the help of a test mandrel and a boring bar tool insert 
setting V-block22, shown in the Fig. 7. Due to progress in machining the cutting tool insert gets worn out which is reflected in the dimension of the CTQ characteristic. In order to compensate the wear in the insert, it is elevated by $0.060 \mathrm{~mm}$ over the diametric dimension every time the wear exceeds $0.060 \mathrm{~mm}$ over the diametric dimension. This

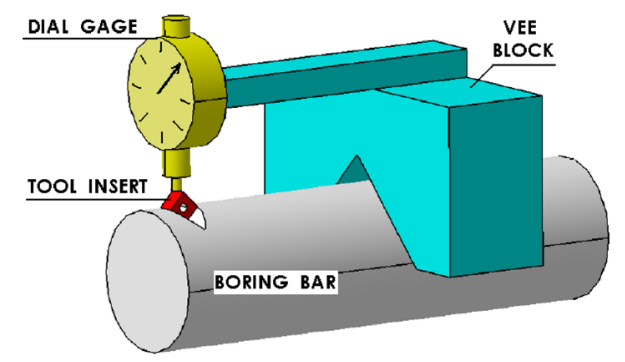

Fig. 7 Schematic diagram of tool insert setting Vee-Block results in a cyclic wear pattern on the dimensions as captured in iteration 4 of Fig. 6 of the process monitoring charts. The contact surfaces of the Vee-Block are case hardened to achieve hardness up to $55 \mathrm{HRc}$. The case depth of hardness is of about $0.5-0.8 \mathrm{~mm}$ in order to sustain wear and tear. Table 6 summarizes the values of process capability indices derived from each improvement Iteration.

\section{Control phase}

After recording the improvements, the real challenge for a process engineering personnel lies in control and sustenance of recording improvements in the $C_{\mathrm{p}}, C_{\mathrm{pk}}$ and $C_{\mathrm{pm}}$ values. In this perspective, the $X$ bar and $R$ control charts are employed as a measure for sustaining improvements.
Table 6 Process capability indices

\begin{tabular}{llcccl}
\hline S. No. & $\begin{array}{l}\text { Capability } \\
\text { index }\end{array}$ & $\begin{array}{l}\text { Iteration 1 } \\
\text { (initial stage) }\end{array}$ & $\begin{array}{l}\text { Iteration 2 (1st } \\
\text { optimization step) }\end{array}$ & $\begin{array}{l}\text { Iteration 3 (2nd } \\
\text { optimization step) }\end{array}$ & $\begin{array}{l}\text { Iteration 4 (3rd } \\
\text { optimization step) }\end{array}$ \\
\hline 1 & $C_{\mathrm{p}}$ & 0.66 & 1.40 & 2.18 & 4.19 \\
2 & $C_{\mathrm{pk}}$ & -0.04 & -0.52 & -1.38 & 3.24 \\
3 & $C_{\mathrm{pm}}$ & 0.27 & 0.22 & 0.18 & 1.41 \\
\hline
\end{tabular}

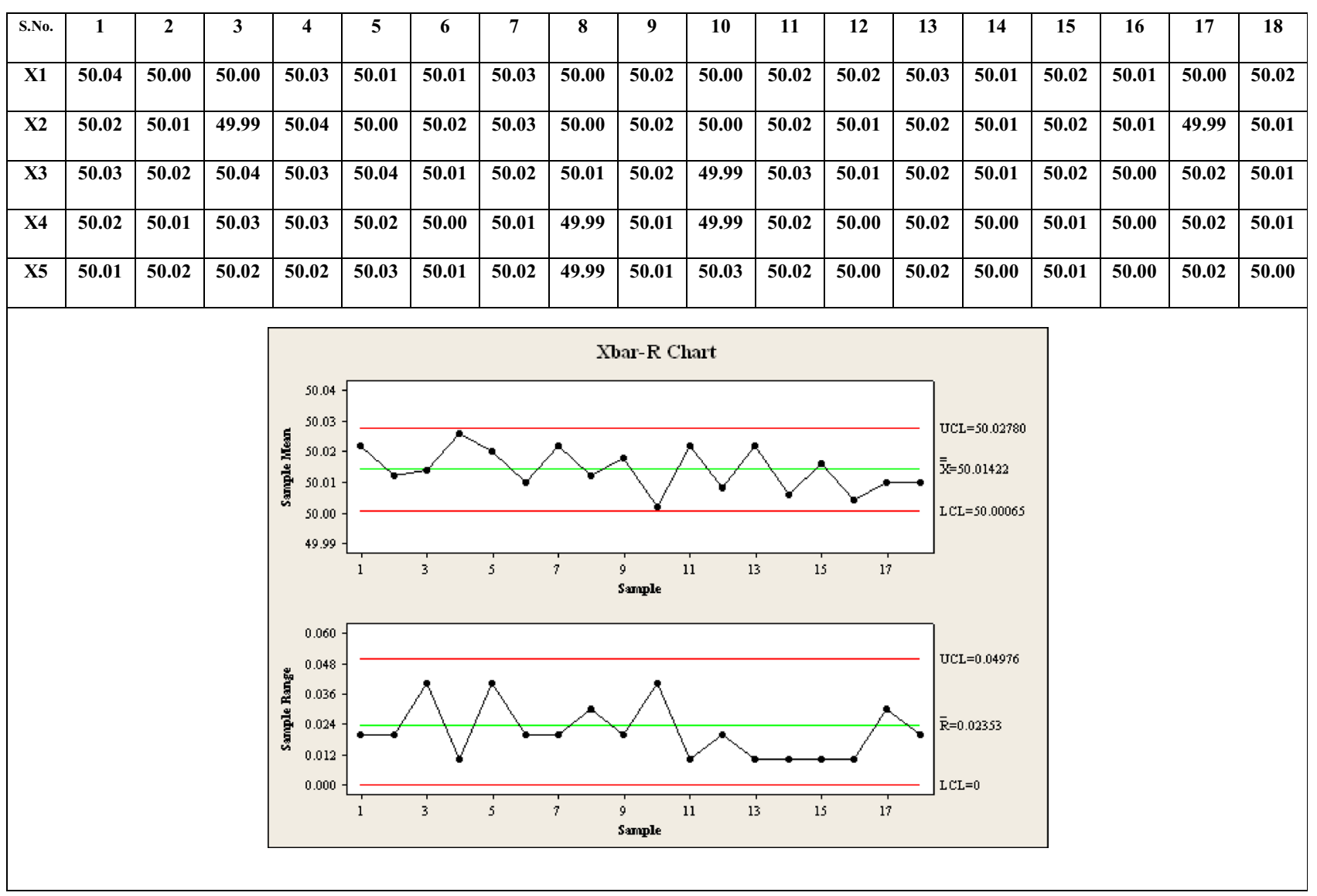

Fig. $8 \bar{X}$ and $R$ control chart 
Table 7 Comparison of process performance with Tolerance Capability Expert software

\begin{tabular}{ll}
\hline Characteristic & Graphical Plot 1 with predicted $\mathrm{C}_{\mathrm{pk}}$ for predetermined tolerance \\
\hline $\begin{array}{l}\text { Center hole diameter after precision boring operation with } \\
\text { process dimension as } \varnothing 50.000 \mathrm{~mm}\end{array}$ & Please refer Fig. 9 \\
\hline $\begin{array}{l}\text { Characteristic } \\
\begin{array}{l}\text { Center hole diameter after precision boring operation with } \\
\text { process dimension as } \varnothing 50.000 \mathrm{~mm}\end{array}\end{array}$ & $\begin{array}{l}\text { Graphical Plot 2 with predicted tolerance for } \\
\text { predetermined } \mathrm{C}_{\mathrm{pk}}\end{array}$ \\
\hline
\end{tabular}

Fig. 9 Graphical plot for center hole diameter precision boring with predicted $C_{\mathrm{pk}}$ of 3.27 for predetermined tolerance of $\pm 0.050 \mathrm{~mm}$

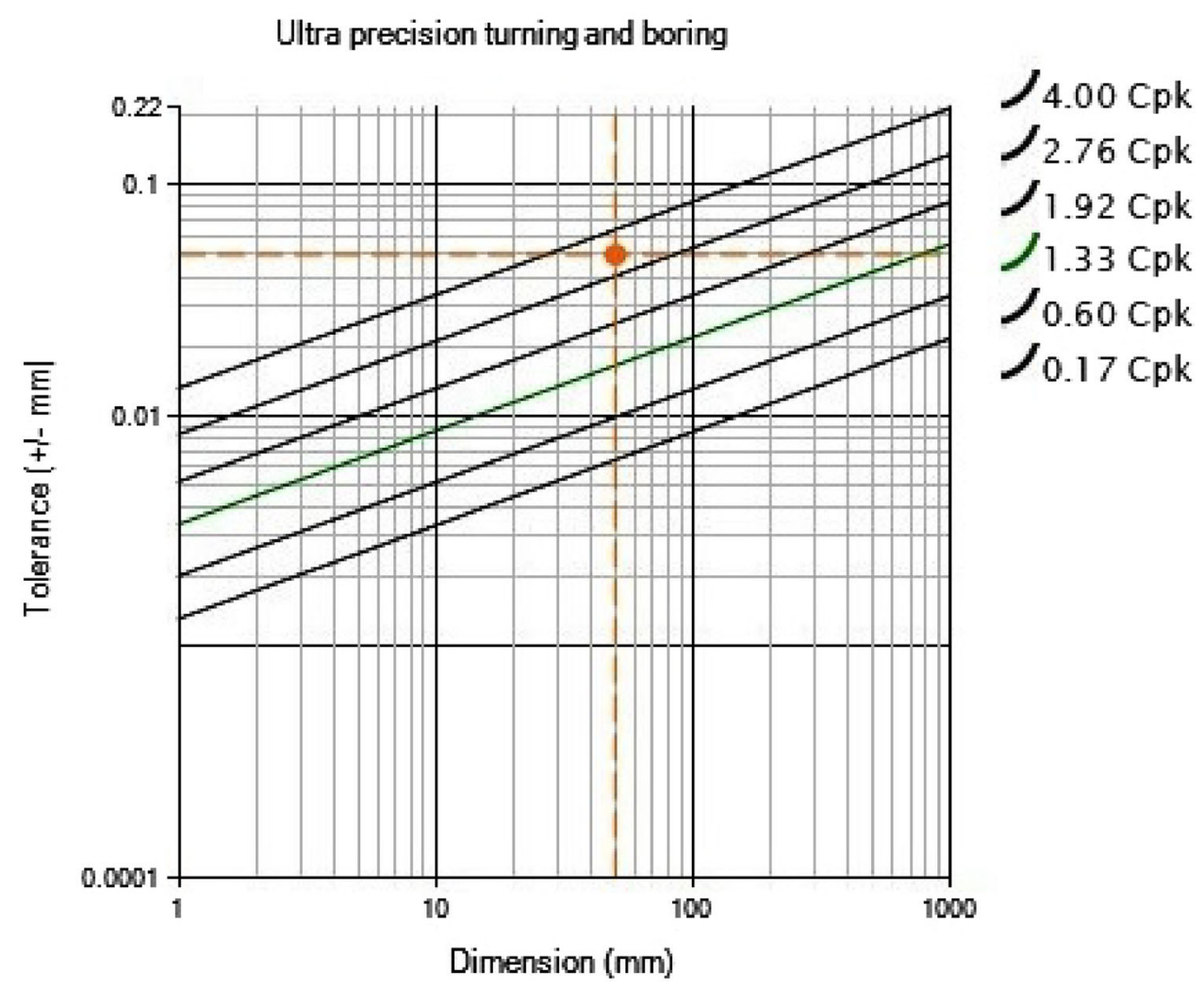

Figure 8 depicts the $X$ bar and $R$ control charts for monitoring the machining process under consideration. The observations from this control phase are from Iteration 3.

Since there are no outliers and no out-of-control subgroups and the values are consistently within the control limits, the CNC alloy wheel machining is declared to be process capable with respect to the CTQ characteristic of center bore hole diameter.

\section{Comparison with a tolerance capability expert software}

The improved Process performance capability index for the center hole diameter of $\varnothing 50.000^{( \pm 0.050)}$ obtained through boring operation is compared with a tolerance capability expert software (https://tce.tolcap.com/login, 2016) as observed by Sharma et al.(2016). The graphical outputs are tabulated in Table 7.

It is observed from the graphical plots of Tolerance Capability Expert software that for center hole diameter precision boring with predetermined tolerance of $\pm 0.050 \mathrm{~mm}$, the predicted $C_{\mathrm{pk}}$ is 3.27 which is almost equal to the obtained final value of 3.24 through this process improvement work. This is depicted in Fig. 9. Also it is observed that for center hole diameter precision boring with predetermined $C_{\mathrm{pk}}$ of 2.000 catering to $6 \sigma$ levels, the predicted tolerance $\pm 0.027 \mathrm{~mm}$ leads to a generous improvement in curtailing down the existing tolerance levels from the existing \pm 0.050 to $\pm 0.027 \mathrm{~mm}$, i.e., almost by $50 \%$. This is reflected in Fig. 10 . 
Fig. 10 Graphical Plot for center hole diameter precision boring with predicted tolerance $\pm 0.027 \mathrm{~mm}$ for predetermined $C_{\mathrm{pk}}$ of 2.000 of $6 \sigma$ levels

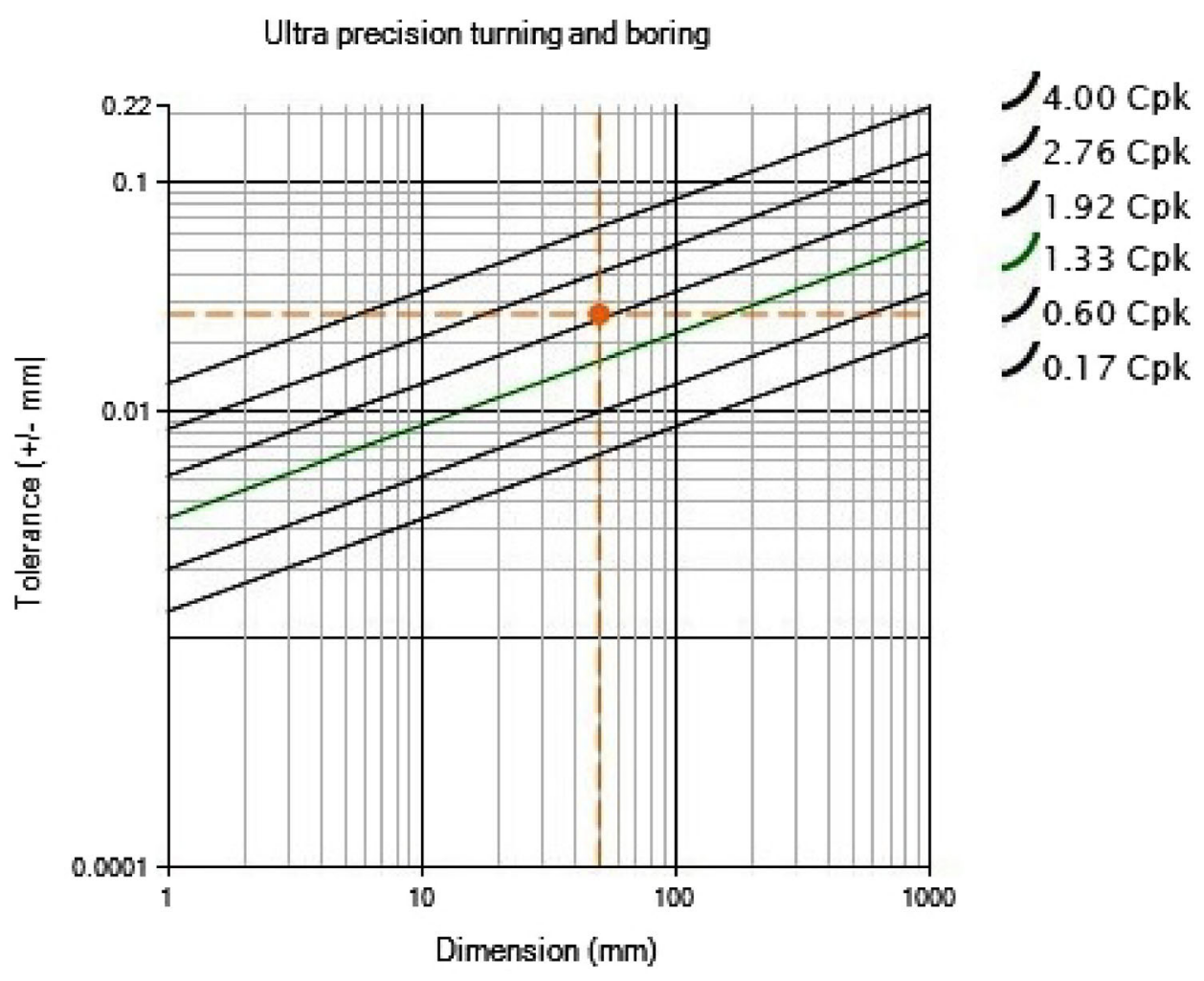

\section{Conclusion}

In this paper, by following the DMAIC approach the CNC machining cell is declared to be a process capable cell, with respect to the identified CTQ characteristic of center hole diameter of $\varnothing 50.000^{( \pm 0.050)}$. The CFT (cross-functional team), apart from increasing the process capability levels of the CNC machining process, also developed a better control over the process by employing the $X$-bar and $R$ control charts at the work shop-floor site. As a result of the process improvement the $C_{\mathrm{p}}, C_{\mathrm{pk}}$ and $C_{\mathrm{pm}}$ improved from an initial value of $0.66,-0.24,0.27$, to a final value of, $4.19,3.24$ and 1.41 , respectively, thereby making the process a statistically capable process. The comparison with tolerance capability expert software strengthens the observation that the process improvement of $C_{\mathrm{pk}}$ equal to 3.24 is achievable and for achieving six sigma levels of $C_{\mathrm{pk}}$ of 2.000 the tolerances can be narrowed down to $0.027 \mathrm{~mm}$, i.e., by about $50 \%$. It can be concluded that the present DMAIC methodology can be readily horizontally deployed as a disciplined problem solving approach for the process engineers to solve the process-related problems in the other manufacturing cells of the A356 aluminum alloy wheel manufacturing process.

Open Access This article is distributed under the terms of the Creative Commons Attribution 4.0 International License (http://crea tivecommons.org/licenses/by/4.0/), which permits unrestricted use, distribution, and reproduction in any medium, provided you give appropriate credit to the original author(s) and the source, provide a link to the Creative Commons license, and indicate if changes were made.

\section{Appendix 1}

Nomenclature

$\mu \quad$ Process mean

$\mu_{i} \quad i$ th value of $\mu$

$\sigma \quad$ Standard deviation

$\sigma^{2} \quad$ Variance

USL Upper specification limit

LSL Lower specification limit

$C_{\mathrm{P}} \quad$ Process potential capability index

$C_{\mathrm{PK}} \quad$ Process performance capability index

$H_{0} \quad$ Null hypothesis

$H_{1} \quad$ Alternative Hypothesis

$x_{i j} \quad$ Data from the $i$ th level and $j$ th observation

$N \quad$ The total sample size

$K \quad$ Number of levels

$\mathrm{SST}_{\mathrm{T}} \quad$ Sum of squared deviations about the grand mean across all $\mathrm{N}$ observations

$\mathrm{SST}_{\mathrm{L}} \quad$ The sum of squared deviations for each level mean about the grand mean

$\mathrm{SST}_{\mathrm{E}} \quad$ The sum of squared deviations for all observations within each level from that level mean 
$\mathrm{MST}_{\mathrm{L}} \quad$ Mean of squared deviations between levels

$\mathrm{MST}_{\mathrm{E}} \quad$ Mean of squared deviations within levels

HSD Honestly significant difference

$Q \quad$ Studentized range statistic

$\eta^{2} \quad$ Eta square, a measure of proportion of the between factor variability to the total variability

$\omega^{2} \quad$ Omega square

$\mathrm{T} \quad$ (Subscript) Total

E (Subscript) Error

L (subscript) Level

Df Degrees of freedom for ANOVA test

\section{Appendix 2}

\section{Analysis of variance (ANOVA)}

ANOVA starts with checking for the assumption about the normality of the data and then formulation of the hypothesis to be tested. A post hoc analysis becomes mandatory if $\mathrm{F}_{\text {STATISTIC }}$ is found to be greater than $F_{\text {CRITICAL }}$.

\section{Testing the assumptions for normality of data and Formulating the Hypothesis}

The pre-requisites for performing one-way ANOVA test is to find departure from normality among the sets of the data. The normal probability plot is seen linear with equispaced values. The $P$ value is less than the $\alpha$ value of 0.05 thereby indicating that a linear relationship exists with normality retained. The results are further strengthened by the fact that there are no unusual data points.

The null hypothesis $\left(H_{0}\right)$ and the alternate hypothesis $\left(H_{1}\right)$ can be formulated in the present context as:

$H_{0}: \mu_{i}=\mu$ all $i=1,2,3,4$

$H_{1}: \mu_{i} \neq \mu$ for some $i=1,2,3,4$ where,

$\mu_{i}$ is the population mean for level $i$, and

$\mu$ is the overall grand mean of all levels.

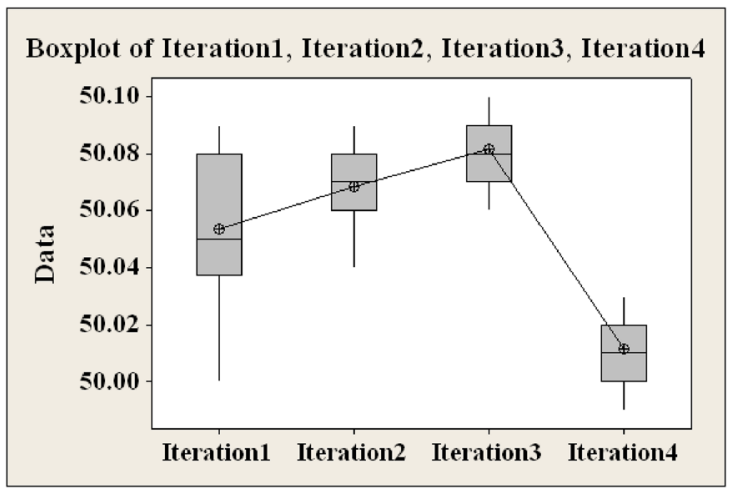

In the present study there are 4 levels (i.e., 4 iterations) with each level consisting of 30 measurement readings of center bore hole diameter of alloy wheel. The box plot and the normal probability plot are captured in Fig. 11.

The dimensional measurement readings of the CTQ characteristic spanning over the four successive Iterations is shown in Table 8

\section{Finding the $\boldsymbol{F}_{\text {STATISTIC }}$}

The ANOVA Table obtained from Minitab software is captured in Table 9. Here it is seen that:

$F_{\text {STATISTIC }}=110.61$

An $\alpha$ value of 0.05 is typically considered, corresponding to $95 \%$ confidence levels. If $\alpha$ is defined to be equal to 0.05 , then, the critical value for rejection region is

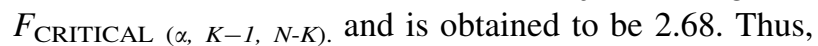

$F_{\text {CRITICAL }}=2.68$

Hence, it is seen that:

$F_{\text {STATISTIC }}>F_{\text {CRITICAL }}$

Therefore, the decision will be to reject the null hypothesis. This indicates that there is at least one of the means $\left(\mu_{i}\right)$ is different from the remaining other means. In order to figure out where this difference lies, a post hoc test is required.

\section{Post-hoc test}

Since here the sample sizes are same, we go for the Tukey's test for conducting the Post-hoc ANOVA test. In Tukey's test, the honestly significant difference (HSD) is calculated as:

$\mathrm{HSD}=q \sqrt{\frac{\mathrm{MST}_{\mathrm{E}}}{n}}=3.92 \sqrt{\frac{25.3 \times 10^{-5}}{30}}=0.0113$

Fig. 11 The box plot and normal probability plot for center bore hole dimensional observations 
Table 8 Dimensional measurement readings of CTQ characteristic

\begin{tabular}{|c|c|c|c|}
\hline S. No. & Iteration 2 & Iteration 3 & Iteration 4 \\
\hline 1 & 50.09 & 50.10 & 50.03 \\
\hline 2 & 50.07 & 50.10 & 50.02 \\
\hline 3 & 50.08 & 50.09 & 50.02 \\
\hline 4 & 50.07 & 50.08 & 50.02 \\
\hline 5 & 50.06 & 50.09 & 50.02 \\
\hline 6 & 50.05 & 50.07 & 50.01 \\
\hline 7 & 50.06 & 50.07 & 50.01 \\
\hline 8 & 50.07 & 50.08 & 50.01 \\
\hline 9 & 50.06 & 50.06 & 50.00 \\
\hline 10 & 50.07 & 50.06 & 50.00 \\
\hline 11 & 50.05 & 50.10 & 50.02 \\
\hline 12 & 50.04 & 50.09 & 50.02 \\
\hline 13 & 50.09 & 50.09 & 50.02 \\
\hline 14 & 50.08 & 50.08 & 50.01 \\
\hline 15 & 50.07 & 50.08 & 50.01 \\
\hline 16 & 50.08 & 50.07 & 50.01 \\
\hline 17 & 50.09 & 50.07 & 50.01 \\
\hline 18 & 50.08 & 50.06 & 50.00 \\
\hline 19 & 50.08 & 50.06 & 50.00 \\
\hline 20 & 50.07 & 50.10 & 50.00 \\
\hline 21 & 50.06 & 50.09 & 50.00 \\
\hline 22 & 50.05 & 50.09 & 49.99 \\
\hline 23 & 50.09 & 50.10 & 50.02 \\
\hline 24 & 50.07 & 50.09 & 50.02 \\
\hline 25 & 50.08 & 50.09 & 50.02 \\
\hline 26 & 50.06 & 50.09 & 50.02 \\
\hline 27 & 50.07 & 50.08 & 50.01 \\
\hline 28 & 50.06 & 50.08 & 50.01 \\
\hline 29 & 50.05 & 50.07 & 50.01 \\
\hline 30 & 50.06 & 50.07 & 50.00 \\
\hline
\end{tabular}

where $q$ is the studentized range statistic which is equal to a value of 3.92, for a degree of freedom of 116 and $k=4$, i.e., number of levels as 4 .

If " $\mathrm{C} 1$ " denotes for "Iteration 1 " and "C2" denotes for "Iteration 2" and "C3" denotes for

"Iteration 3", and "C4" denotes for Iteration 4, then from Minitab software, the following Grouping Information using Tukey method is shown in Table 8:

From Table 10, it is inferred that Means that do not share a letter are significantly different, i.e., all the Iterations are significantly different from each other.

The pairwise comparison using Minitab is depicted in Table 11.

In the Table 11, it is seen that all the pairwise comparison between the Iterations are greater than that of the HSD in Eq. (5), with the difference between $\mathrm{C} 3$ and $\mathrm{C} 4$ is 0.07033 , being the largest. So, it is deduced that the differences are
Table 9 The ANOVA Table

\begin{tabular}{lrllll}
\hline \multicolumn{5}{l}{ One-way } & ANOVA: Iteration 1, Iteration 2, Iteration 3, Iteration 4 \\
\hline Source & DF & \multicolumn{1}{l}{ SS } & MS & $F$ & \multicolumn{1}{l}{$P$} \\
\hline Factor & 3 & 0.084036 & 0.028012 & 110.61 & 0.000 \\
Error & 116 & 0.029377 & 0.000253 & & \\
Total & 119 & 0.113412 & & & \\
\hline
\end{tabular}

Table 10 Grouping information using Tukey method

\begin{tabular}{llll}
\hline Iteration Column 'C' & $N$ & Mean & Grouping \\
\hline C1 & 30 & 50.08167 & A \\
C2 & 30 & 50.06867 & B \\
C3 & 30 & 50.05333 & C \\
C4 & 30 & 50.01133 & D \\
\hline
\end{tabular}

Table 11 Pairwise comparisons of Iterations

\begin{tabular}{lll}
\hline S. No. & Pairwise comparison & Value \\
\hline 1 & C1 subtracted from: C2 & 0.01533 \\
2 & C1 subtracted from: C3 & 0.02833 \\
3 & C1 subtracted from: C4 & 0.04200 \\
4 & C2 subtracted from: C3 & 0.01300 \\
5 & C2 subtracted from: C4 & 0.05733 \\
6 & C3 subtracted from: C4 & 0.07033 \\
\hline
\end{tabular}

statistically significant. Hence, it is concluded that among all the different causes enumerated in the causal matrix, the most influencing causes are those in Iteration 3, namely, the improper tool insert setting v-block, inaccuracies in setup changeover and undue machine stoppage. The extent of influence is given by eta-square $\left(\eta^{2}\right)$. It measures the proportion of "the between factor variability" to "the total variability" and is given by:

$$
\begin{aligned}
\eta^{2} & =\frac{\text { sum of square between the levels }}{\text { sum of squares across all the } 96 \text { observations }} \\
& \Rightarrow \eta^{2}=\frac{0.084036}{0.113412}=0.7409=74.09 \%=74 \%
\end{aligned}
$$

Eta-square is just a ratio of treatment effect variability to total variability. One drawback with eta-square is that it is a biased estimate and tends to overestimate the effect. A more accurate measure of the effect is the omega-square $\left(\omega^{2}\right)$ given by:

$$
\begin{aligned}
\omega^{2} & =\frac{S S T_{G}-(k-1) M S T_{E}}{S S T_{T}+M S T_{E}} \\
& \Rightarrow \omega^{2}=\frac{0.083277}{0.113665}=0.73265=73.265 \%=73 \%
\end{aligned}
$$

Hence, from above Eq. (6) it is deduced that $73 \%$ of variability is due to the causes addressed in Iteration 3, i.e., 
improper tool insert setting v-block, inaccuracies in setup changeover and undue machine stoppage.

\section{References}

Burlikowska MD (2005) Quality estimation of process with usage control charts type X-R and quality capability of process $C_{p}, C_{p k}$. J Mater Process Technol 2005(162-163):736-743

Chen JC, Li Y, Cox RA (2009) Taguchi-based Six Sigma approach to optimize plasma cutting process: an industrial case study. Int J Adv Manuf Technol 41:760-769

Chen WL, Huang CY, Huang CY (2013) Finding efficient frontier of process parameters for plastic injection molding. J Ind Eng Int 9:25

Desai DA, Kotadiya P, Makwana N, Patel S (2015) Curbing variations in packaging process through six sigma way in a large-scale foodprocessing industry. J Ind Eng Int 11(1):119-129

Du Shichang, Huang Delin, Lv Jun (2013) Recognition of concurrent control chart patterns using wavelet transform decomposition and multiclass support vector machines. Comput Ind Eng 66(4):683-695

Gentili E, Aggogeri F, Mazzola M (2006) The improvement of a manufacturing stream using the DMAIC method. ASME 2006 international mechanical engineering congress and exposition. pp 127-133

Hwang YD (2006) The practices of integrating manufacturing execution system and six sigma methodology. Int J Adv Manuf Technol 30:761-768

John WL (1994) Statistical measurement control. Quality and statistics: total quality management, ASTM STP 1209, Milton J. Kowalewski, Jr., Ed., American Society for Testing and Materials, Philadelphia

Kumaravadivel A, Natarajan U (2013) Application of six-sigma DMAIC methodology to sand-casting process with response surface methodology. Int J Adv Manuf Technol 69(5-8):1403-1420

Lal AK, Kaur M, Lata MS (2013) Behavioral study of piston manufacturing plant through stochastic models. J Ind Eng Int 9:24

Lange K, Leggett S, Baker B (2001) Potential failure mode and effects analysis (FMEA) reference manual. AIAG, Southfield

Li MHC, Al-Refaie A, Yang CY (2008) DMAIC approach to improve the capability of SMT solder printing process. IEEE Trans Electron Packag Manuf 31(2):126-133
Lin HC (2004) The measurement of a process capability for folded normal process data. Int J Adv Manuf Technol 24:223-228

Lin SJ, Yang DL, Cheng FT, Wu MF (2013) Aircraft turbine engine manufacturing with multiple specifications. J Test Eval 41(1):1-7

Lo WC, Tsai KM, Hsieh CY (2009) Six Sigma approach to improve surface precision of optical lenses in the injection-molding process. Int J Adv Manuf Technol 41:885-896

Mariajayaprakash A, Senthilvelan T, Vivekananthan KP (2013) Optimisation of shock absorber process parameters using failure mode and effect analysis and genetic algorithm. J Ind Eng Int 9:18

Sahay C, Ghosh S, Bheemarthi PK (2011) Process improvement of brake lever production using DMAIC $(+)$. In: ASME 2011 international mechanical engineering congress and exposition, vol 3, pp 801-826

Schilling EG (1994) The transition from sampling to SPC. Quality and statistics: total quality management, ASTM STP1209, Milton J.Kowalewski, Jr. Ed., American Society for Testing and Materials, Philadelphia

Sharma GVSS, Rao PS (2013) Process capability improvement of an engine connecting rod machining process. J Ind Eng Int 9:37

Sharma GVSS, Rao PS (2014) A DMAIC approach for process capability improvement an engine crankshaft manufacturing process. J Ind Eng Int 10:65

Sharma GVSS, Rao PS, Babu BS (2016) Process-based tolerance assessment of connecting rod machining process. J Ind Eng Int 12:02

Singh R (2011) Process capability study of polyjet printing for plastic components. J Mech Sci Technol 25(4):1011-1015

Su CT, Chiang TL, Chiao K (2005) Optimizing the IC delamination quality via six-sigma approach. IEEE Trans Electron Packag Manuf 28(3):241-248

Su CT, Hsiao YH, Liu YL (2012) Enhancing the fracture resistance of medium/small-sized TFT-LCDs using the six sigma methodology. IEEE Trans Compon Packag Manuf Technol 2(1):149-164

Tce.tolcap.com (2016) "Tolcap" tolerance capability expert software. https://tce.tolcap.com/. Accessed 13 Dec 2016

Tong JPC, Tsung F, Yen BPC (2004) A DMAIC approach to printed circuit board quality improvement. Int J Adv Manuf Technol 23:523-553

$\mathrm{Yu}$ KT, Sheu SH, Chen KS (2007) The evaluation of process capability for a machining center. Int J Adv Manuf Technol 33:505-510 